\title{
Analisis Pendapatan Pedagang Koran Asongan di Kota Pekanbaru Provinsi Riau
}

\author{
WITA DWIKA LISTIHANA \\ AFVAN AQUINO \\ Jurusan Manajemen Fakultas Ekonomi \\ Universitas Lancang Kuning \\ J1. Yos Sudarso KM. 08 Rumbai - Pekanbaru
}

\begin{abstract}
This Research is aimed to analyze causal factors of the school-age children choosing to work as street newspaper seller, how the pattern of work activity is done, and their participation to family prosperity. The method of this research used survey approach. The sample of this research amount of 40 respondent and used the purposive sampling technique. The research location is in Pekanbaru City, Riau Province with took the location in road intersection of traffic light. The type of data used the primary data by spreading questionnaires and the data analysis in this research used the descriptive-kualitatave. The result showed that factors that caused of school-age children choose to work as street newspaper seller consist of three factors. First, the reason for choosing the job, in this issue at most because of the own disires that is $80 \%$ respondents. Second, the reason for doing the job, at most to support family's economic that is $60 \%$ respondents. Third, motivation become a street newspaper seller, at most to get the money that is $75 \%$ respondets. Furthermore, the pattern of work activity that is done by road news paper seller can show in three things that are the way of selling, the time of selling and kinds of news papers that is sold. First, the majority of street newspaper seller do the selling with take news papers in an agent or a coordinator that related to the owner's of news paper that is 77,5\% respondents. Second, the time of selling at most is in the morning until the day that is 42,5\% respondent.Third, 82,5\% respondent sell more than two kinds of news paper. Finally, Their participation into family prosperity is showed by amount of income and the using of income that is received. First, amount of income at most is the income under Rp 50.000,- that is $62,5 \%$ respondents. Second, the using of income at most is for school needs and to support their parents that is $37,5 \%$ respondents.
\end{abstract}

Keywords: Income, Street newspaper seller, and School-age children

Pada saat sekarang ini dimana tingkat kebutuhan hidup yang semakin meningkat, mencari nafkah semakin sulit, tingkat kemiskinan semakin meningkat, lapangan pekerjaan menjadi sulit dan tingkat pengangguran semakin bertambah, hal ini telah menyebabkan banyak masyarakat, khususnya masyarakat yang berada pada posisi di lapisan masyarakat bawah terpaksa bekerja disektor informal untuk mendapatkan ataupun menambah penghasilan keluarga.

Kota Pekanbaru pada saat ini banyak terdapat pedagang informal, baik pedagang kaki lima maupun pedagang asongan sehingga dengan adanya pedagang tersebut menyebabkan jalan-jalan lalu lintas menjadi macet dan dapat merusak keindahan kota, karena sulitnya mengatur tata ruang bagi mereka untuk menempati tempat-tempat yang sudah diatur dan ditentukan oleh pemerintah.

Selain itu, sektor informal lainnya yang banyak terlihat di sepanjang jalan dan tempat berhentinya kendaraan atau lampu rambu-rambu lalu lintas (trafic light) adalah Pedagang Koran Asongan dimana pedagang-pedagang tersebut dari pagi sampai malam hari masih selalu terlihat secara bergantian menjajakan koran dagangannya dari mulai orang tua, anak usia sekolah sampai anak usia pra sekolah yang bekerja menjual Koran. Hal ini sebenarnya akan merusak nama baik sebuah administrasi di suatu perkotaan terutama bagi dinas tenaga kerja karena sudah melanggar ketentuan undang-undang ketenagakerjaan. Selain itu, hal tersebut merusak keindahan dan ketertiban kota karena mereka bekerja selalu berkumpul di 
suatu tempat pusat-pusat kota yang ramai dilalui pengendara baik itu sepeda motor maupun mobil.

Dari pekerjaan yang mereka lakukan tersebut dapat mengakibatkan kecelakaan pada diri mereka sendiri karena mereka sering mengejar dan menjajakan korannya kepada para pengendara yang sedang lewat ataupun berhenti di persimpangan lampu merah. Adakalanya mereka dipanggil oleh pengendara yang akan membeli korannya pada saat lampu mulai hijau sehingga mereka berlari-lari tanpa menghiraukan kendaraan yang akan lewat. Dengan demikian, Pekerjaan ini mempunyai resiko kecelakaan yang sangat besar.

Hasil dari pekerjaan tersebut tidak lain adalah pendapatan yang diharapkan dapat mencukupi kebutuhan mereka, oleh karena itu mereka dengan semangat selalu menjajakan korannya dengan tidak mengenal waktu dan tempat, hal ini akan menyebabkan terjadiya perubahan sosial bagi kehidupan masyarakat di suatu tempat karena mereka juga ingin maju dan ingin pintar serta berhasil dengan baik, demi kebutuhan hidupnya mereka sanggup meninggalkan bangku sekolah untuk mendapatkan nilai rupiah yang dibutuhkan.

Sejauh ini belum banyak penelitian yang membahas mengenai apa sesungguhnya yang menjadi motivasi anak-anak tersebut untuk terlibat di dalam pekerjaan menjadi pedagang koran asongan sehingga akan dapat melalaikan kewajibannya sebagai anak sekolah yang menjadi penerus bangsa dan calon-calon pemimpin. Berdasarkan uraian diatas maka penulis berminat untuk melakukan penelitian dengan judul: Analisis Pendapatan Pedagang Koran Asongan di Kota Pekanbaru Provinsi Riau. Dari penelitian ini, diharapkan dapat memberi masukan yang berarti bagi pemerintah Kota Pekanbaru terutama pada dinas atau lembaga terkait seperti: Dinas Sosial, Dinas Tenaga Kerja, Dinas Pendidikan dan Kebudayaan, serta Satpol PP agar lebih memperhatikan mengenai perkembangan jumlah dan perilaku para pedagang asongan tersebut.
Secara teori sumber daya manusia bukan hanya sekedar sarana untuk memikul beban pembangunan, tetapi harus merupakan sasaran utama dari pembangunan. Dimana pembangunan manusia yang dicanangkan sebagai titik sentral pembangunan Nasional bukanlah semata-mata untuk mensukseskan pembangunan tetapi justru pembangunan itu sendiri harus ditujukan untuk manusia.

Lapangan kerja disektor informal bukan lapangan kerja sementara, tetapi merupakan pekerjaan yang relative permanen dan stabil. Relatif banyaknya tenaga kerja kelompok umur produktif yang terlibat didalamnya, relatif cukup lamanya mereka menekuni pekerjaan ini. Lapangan kerja sektor informal dalam pilihan bekerja merupakan indikator yang dapat dijadikan tolak ukur bahwa lapangan kerja sector informal bukanlah media sementara atau batu loncatan sebelum seseorang memperoleh pekerjaan disektor formal. (Nur Hidayah; 2012)

Menurut Loekman Soetrisno dalam Agung Ridho (2001; 31) sektor informal bukanlah suatu fenomena yang baru, sektor informal muncul ditengah kita sejak manusia berada didunia ini. Sejak manusia ada didunia mereka telah menunjang kehidupannya dengan menciptakan lapangan kerja sendidri atau sektor informal (self employed ). Indrawati dalam Susanti Ningsih (2012;25) menjelaskan bahwa kriteria yang dapat dipakai untuk menerangkan sektor informal antara lain tingkat umur, pendidikan dan jam kerja sebagai indikator untuk menggambarkan karakteristik pekerja sektor informal. Dimana sektor informal tidak mengenal batasan umur, pekerja sektor informal itu umumnya berpendidikan rendah dan jam kerja yang tidak teratur.

Aktivitas di bidang usaha merupakan salah satu aktivitas yang pokok dalam rangka mempertahankan hidup manusia. Aktivitas usaha ini banyak dipengaruhi oleh lingkungan ekonomi, lingkungan social, lingkungan alam dan lingkungan kenegaraan. (Dessy 
Arifianto;2006;69). Menurut Sarjono Soekanto dalam Ibrahim $(2003 ; 14)$ dasar dari terjadinya interaksi social adalah kontak social yang didefinisikan sebagai pengaruh timbal balik antara berbagai segi kehidupan bersama serta menyatakan bahwa interaksi sosial adalah dasar dari proses-proses sosial. Dalam pengertian tersebut diatas interaksi social menunjukan pada hubungan-hubungan social yang dinamis.

Strategi bertahan hidup adalah sebagai rangkaian tindakan yang dipilih secara standart oleh individu dan rumah tangga yang miskin secara social ekonomi. Melalui strategi ini seseorang bisa berusaha menambah penghasilan lewat pemanfaatan sumber-sumber lain ataupun mengurangi pengeluaran lewat pengurangan kuantitas dan kualitas barang atau jasa. (Snal dan Staring dalam Resmi Setia; 2005; 6). Selanjutnya menurut pendapat MC Clelland dalam Robinson (2007;230) menyatakan bahwa individu dengan prestasi yang tinggi membedakan diri mereka dari individu lain menurut keinginan mereka untuk melakukan hal-hal yang lebih baik. Mereka mencari situasi-situasi dimana bias mendapatkan tanggup jawab pribadi guna mencari solusi atas bebagai masalah, bias menerima umpan balik yang cepat tentang kinerja sehingga dapat dengan mudah mereka berkembang atau tidak dan dimana mereka bias menentukan tujuan-tujuan yang cukup menantang.

Menurut Hafsah (2003 ; 70) dalam bukunya menyatakan pendapatan usaha yaitu semua output yang dihasilkan dari suatu kegiatan tertentu, dalam prakteknya, mengusahakan pekerjaan tertentu menggunakan berbagai macam cara dengan demikian maka hasil usaha yang di peroleh juga merupakan penjumlahan dari seluruh output yang dihasilkan. Sedangkan Nasution (2002: 216) memberikan batasan bahwa pendapatan usaha dinilai dari besarnya volume usaha (omzet) yang di indikasikan dari nilai tambah bagi usahawan sebagai keikutsertaan dalam suatu kegiatan usaha atau pekerjaan tertentu.
Sadono Sukirno menceritakan dalam buku ekonomi Mikro, bahwa pendapatan rumah tangga adalah penghasilan dari seluruh anggota rumah tangga yang disumbangkan untuk memenuhi keluarga ataupun perorangan anggota rumah tangga. Pendapatan seseorang dapat berubah-rubah dari waktu kewaktu sesuai dengan kemampuan mereka. Oleh sebab itu dengan berubahnya pendapatan seseorang akan berubah pula besarnya pengeluaran mereka untuk mengkonsumsi suatu barang. Jadi, pendapatan merupakan faktor yang penting dalam mempengaruhi konsumsi seseorang atau masyarakat terhadap suatu barang (Sukirno: 2002; 37).

Distribusi pendapatan adalah pengukuran untuk mengukur kemiskinan relatif. Distribusi pendapat biasanya diporoleh dengan menggabungkan seluruh individu dengan menggunakan skala pendapatan perorang kemudian dibagi dengan jumlah penduduk kedalam kelompok-kelompok berbeda berdasarkan pengukuran atau jumlah pendapatan yang diterima. (Reni dan Tjiptoherijanto: 2002; 40-41) Menurut Boediono (2002; 170) beberapa faktor yang mempengaruh tingkat pendapatan seseorang adalah: Jumlah faktor produksi yang dimiliki dari hasil produksi barang dan jasa. Harga per unit dari masing-masing faktor produksi. Harga ini ditentukan oleh kekuatan permintaan dan penawaran di pasar faktor produksi.

\section{METODE}

Penelitian ini dilakukan dengan pendekatan survey, yaitu dengan menggunakan data sekunder dan data primer dari responden terhadap objek-objek yang ditanyakan. Sesuai dengan permasalahan dan tujuan yang ingin dijawab, maka dilakukan pendiskripsian data kuantitatif ditambah dengan interprestasi data-data kualitatif. Penelitian ini dilaksanakan di kota Pekanbaru Propinsi Riau, dengan mengambil lokasi dipersimpangan jalan lampu lalu lintas yang 
banyak berjualan pedagang koran asongan. Populasi dalam penelitian ini adalah pedagang koran asongan yang ada dikota Pekanbaru yang berlokasi dipersimpangan jalan lampu lalu lintas sedangkan yang menjadi responden diambil melalui pengambilan sampel secara purposive sampling sebanyak 40 orang yang masih berusia sekolah dengan rincian sebagai berikut : Lokasi Jalan Sudirman (Perempatan JL. Harapan Raya) sebanyak 10 orang. Lokasi jalan Sudirman (Perempatan Gramedia) sebanyak 10 orang. Lokasi jalan Diponegoro sebanyak 10 orang dan lokasi jalan Nangka depan Mall SKA sebanyak 10 orang

Jenis data yang digunakan dalam penelitian ini adalah data kualitatif dan data kuantitatif sedangkan sumber data yang penulis gunakan adalah data primer dan data sekunder. Data primer penulis dapatkan dari hasil penelitian responden dilapangan sedangkan data sekunder penulis peroleh dari sumber-sumber tertulis mengenai gambaran umum daerah penelitian, keadaan penduduk dan data lainnya yang mendukung.

Teknik pengumpulan data dalam penelitian ini dapat penulis peroleh dari: Interview atau wawancara langsung dengan responden. Penyebaran angket atau daftar pertanyaan yang sesuai dengan maksud dan tujuan dari penelitian ini. Studi Kepustakaan yang tujuannya untuk menambah wawasan literature atau bahan bacaan yang dapat menunjang penelitian ini. Analisis data yang dilaksanakan dalam penelitian ini adalah menggunakan metode deskriptif kualitatif, yaitu data-data yang diperoleh dari hasil interview dan pengisian kuestioner akan dibahas secara menyeluruh berdasarkan kenyataan yang terjadi pada saat penelitian dilaksanakan, kemudian penulis akan membandingkan dengan konsep maupun teori-teori yang dapat mendukung pembahasan terhadap permasalahan dalam penelitian ini, kemudian mengambil kesimpulan yang berlaku secara umum.

\section{HASIL}

Dilihat dari dampak positipnya, tanpa disadari ternyata pedagang koran asongan telah banyak membantu para pengguna jalan yang ingin membaca koran tidak harus pergi kewarung-warung atau tempat penjualan koran yang lain karena mereka sudah dapat membelinya secara langsung disimpang jalan. Adapun koran yang dijual oleh pedagang koran asongan sebagai berikut: Koran Riau Pos, Koran Tribun, Koran Metro Riau, Koran Haluan Riau, Koran Pekanbaru Pos, Koran MX dan Koran Vokal. Dari hasil penelitian dan wawancara dilapangan, koran yang paling laku atau laris dibeli oleh masyarakat adalah Koran Riau Pos, kemudian Koran Tribun, yang memegang urutan ketiga adalah Koran MX dan yang paling sedikit dijual dan diminati oleh masyarakat adalah adalah Koran vokal. Dari hasil penelitian di lapangan yang kami peroleh bahwa terdapat tujuh orang anak perempuan dan 33 orang anak laki-laki. Lokasi yang mereka jadikan tempat berjualan biasanya sudah ditentukan oleh masing-masing koordinator namun mereka bisa berpindah tempat sesuai dengan kesepakatan bersama.

Dari hasil penelitian membuktikan bahwa jumlah pedagang koran asongan yang bekerja setiap hari yang terbanyak adalah berumur 11 sampai dengan 15 tahun yaitu berjumlah 21 orang $(52,5 \%)$, sedangkan anak-anak yang berumur dibawah 10 tahun berjumlah 7 orang $(17,5 \%)$ sedangkan yang berumur 16 sampai 20 tahun berjumlah 12 orang (30\%). Hal ini menunjukan bahwa mereka semua berada di usia sekolah namun sudah dapat bekerja mencari nafkah, demi kebutuhan hidup yang mereka pertahankan untuk masa depannya.

Dari hasil penelitian terbukti bahwa tingkat pendidikan pedagang koran asongan sebagian besar adalah berpendidikan sekolah dasar yaitu sebanyak 19 orang $(47,5 \%)$, yang berpendidikan SMP sebanyak 14 orang ( $35 \%$ ) dan yang berpendidikan SMA adalah sebanyak 7 
orang ( $17,5 \%)$. Dari tingkat pendidikan tersebut, tidak semuanya yang masih aktif sekolah, sebagian dari mereka sudah tidak sekolah lagi. Dari hasil penelitian dapat dilketahui bahwa pedagang Koran asongan yang masih aktif sekolah, ternyata pendidikan yang terbanyak adalah sekolah dasar (SD) yaitu sebanyak 16 orang (40\%) pendidikan SMP sebanyak 9 orang $(22,5 \%)$ dan yang paling sedikit adalah tingkat pendidikan SMA yaitu sebanyak 2 orang (5\%) hal ini disebabkan karena pendidikan SMA masih dapat bekerja diperusahaan atau dikantor-kantor yang mereka inginkan, sedangkan yang lainnya tidak bersekolah lagi yaitu sebanyak 13 orang $(32,5 \%)$.

Dari hasil penelitian dapat diketahui bahwa pedagang koran asongan yang banyak berjualan di Kota Pekanbaru adalah di lokasi sepanjang jalan Sudirman, terutama perempatan Jalan Harapan Raya dan Jalan Sudirman, persimpangan Gramedia, dan persimpangan Polda Riau atau bundaran depan Kantor Gubernur Riau. Lokasi ini merupakan lokasi yang paling banyak digemari oleh para penjual koran karena mereka mengangggap jalan tersebut adalah jalan utama yang sering dilalui oleh masyarakat banyak. Hal ini terlihat dari hasil di lapangan yaitu sebanyak 15 orang pedagang asongan menempati lokasi tersebut yaitu sebesar 37,5\%, kemudian jalan Arengka tepatnya didepan Mall SKA yaitu sebanyak 12 orang (30\%), jalan harapan raya sebanyak 8 orang (20\%). Junlah yang paling sedikit adalah jalan Dipenegoro yaitu sebanyak 5 orang $(12,5 \%)$ karena disini letaknya dekat dengan jalan Sudirman yaitu tepatnya di persimpangan bundaran lampu lalu lintas di depan kantor Polda Riau sehingga mereka sering berpindah-pindah tempat.

Dari hasil penelitian juga dapat diketahui bahwa lamanya mereka bekerja sebagai pedagang Koran asongan dikota Pekanbaru sebanyak 22 orang $(55 \%)$ bekerja sudah lebih dari dua tahun,hal ini mereka lakukan karena belum mendapatkan pekerjaan lain yang lebih baik, sedangkan 11 orang $(27,5 \%)$ belum sampai satu tahun dan sebanyak 7 orang $(17,5 \%)$ bekerja lebih dari satu tahun.

\section{PEMBAHASAN}

Dari hasil penelitian yang telah diuraikan maka dapat dibahas dan dijelaskan beberapa hal yang dapat menganalisis Pendapatan Pedagang Koran Asongan dikota Pekanbaru yaitu sebagai berikut :

\section{Faktor-faktor Penyebab Memilih Pekerjaan Sebagai Pedagang Asongan \\ Ada tiga faktor yang} mempengaruhinya untuk melaksanakan pekerjaan tersebut yaitu: alasan memilih pekerjaan, alasan melakukan pekerjaan dan motivasi sebagai pedagang koran asongan. Dari ketiga faktor tersebut dapat

Dari tabel tersebut dapat dilihat bahwa faktor yang mempengaruhi responden bekerja sebagai pedagang Koran Asongan adalah yang pertama alasan melakukan pekerjaan disebabkan karena keinginan sendiri yaitu sebanyak 32 orang $(80 \%)$, dari hasil wawancara dilapangan mereka mengatakan bahwa pekerjaan sebagai pedagang Koran asongan tidak memerlukan persyaratan yang berat seperti melamar kerja disebuah perusahaan atau kantor, sehingga mereka mempunyai inisiatif sendiri untuk melakukan pekerjaan tersebut dan mereka bekerja tidak ada ikatan yang kuat, kalau Koran- Koran tersebut tidak laku terjual maka dapat dikembalikan lagi keagen atau coordinator, kemudian alasan karena disuruh orang tua sebanyak 2 orang $(5 \%)$ dan alasan karena ingin mencari Pengalaman adalah sebanyak 6 orang $(15 \%)$.

Faktor yang kedua adalah alasan responden untuk melakukan pekerjaan sebagai pedagang Koran asongan bahwa sebagian besar responden memilih pekerjaan sebagai pedagang Koran asongan adalah untuk membiayai keperluan sekolahnya, karena mereka merasa orang tua sudah tidak sanggup lagi untuk membiayai sekolah mereka, hal ini dapat 
terlihat sebanyak 11 orang $(27,5 \%)$ menyatakan bahwa alasan untuk melakukan pekerjaan sebagai pedagang Koran asongan adalah untuk membiayai keperluan sekolahnya. Kemudian 24 orang (60\%) menjawab untuk membantu Ekonomi keluarga dan sebanyak 5 orang $(12,5 \%)$ untuk membiayai keperluan sendiri.

Selanjutnya bagaimana motivasi mereka sebagai anak usia sekolah bekerja mencari nafkah sebagai penyambung hidupnya, bahwa motivasi responden melakukan pekerjaan sebagai pedagang Koran asongan yang paling dominan adalah untuk mendapatkan uang yaitu berjumlah 30 orang $(75 \%)$, karena uang tersebut memang sangat dibutuhkan oleh mereka untuk biaya sekolah dan biaya hidupnya. Kemudian yang menjawab untuk menambah pengetahuan dalam bekerja sebanyak 6 orang $(15 \%)$ sedangkan yang menyatakan untuk menambah pergaulan sebanyak 4 orang ( $15 \%)$.

\section{Pola Kegiatan Pekerjaan Responden}

Untuk mengetahui bagaimana caranya para responden tersebut menjual koran bahwa cara responden dalam melakukan penjualan korannya dibawah naungan koordinator yaitu sebanyak 31 orang $(77,5 \%)$, maksudnya disini adalah mereka mengambil koran-koran tersebut setiap harinya lewat agen penjualan atau yang disebut dengan koordinator, identitas mereka sudah tercatat oleh masing-masing koordinator, mereka diberikan kebebasan untuk menjual berbagai jenis koran dengan jumlah yang ditentukan oleh masing-masing koordinator, mengenai lokasi penjualan sudah ditentukan, namun mereka masih bisa bebas memilih lokasi sesuai dengan kondisi daerah masing-masing dan kesanggupan mereka untuk menjangkaunya.

Selain cara menjual, waktu menjual koran juga merupakan hal terpenting bagi mereka untuk menjajakan korannya, karena sebagian besar dari mereka masih berstatus sebagai pelajar, oleh karena itu diluar jam sekolah mereka baru bisa menjual Koran tersebut, bahwa pedagang koran asongan yang terbanyak adalah berjualan dari pagi sampai siang hari yaitu berjumlah 17 orang $(42,5 \%)$ kemudian malam hari sebesar 14 orang $(35 \%)$ dan siang sampai malam berjumlah 9 orang $(22,5 \%)$. Bagi mereka yang sekolah pada pagi hari biasanya mereka memilih bekerja pada waktu siang hari atau malam hari, kemudian yang bersekolah siang hari mereka memilih bekerja pagi hari sampai siang atau malam hari.

Untuk jenis koran yang dijualnya, masing-masing orang berbeda antara yang satu dengan yang lainnya $\mathrm{Hal}$ ini tergantung pada kesanggupan masing-masing individu untuk menjualnya. Untuk dapat melihat berapa macam jenis koran yang dijual oleh masing-masing pedagang bahwa rata-rata jumlah jenis Koran yang dijual oleh para pedagang Koran asongan ini adalah lebih dari dua macam yaitu sebanyak 33 orang responden atau sebesar $82,5 \%$.

\section{Partisipasi Terhadap Kesejahteraan Keluarga}

Dari hasil penelitian yang penulis peroleh di lapangan, ternyata pendapatan yang mereka terima sebagian diberikan kepada orang tuanya dan sebagian lagi mereka pakai untuk kebutuhan sekolah dan kebutuhan pribadi mereka masing-masing. Adapun tingkat keuntungan penjualan koran yang mereka terima masing-masing berbeda tergantung berapa banyak mereka laku terjual dan masing-masing jenis koran harganya berbeda-beda dengan kisaran harga keuntungan per lembar Rp 500 s/d Rp 800, dengan rincian sebagai berikut :

1. Koran Riau Pos harga dari agen/koordinator Rp 3.800 sedangkan harga jualnya $\mathrm{Rp} 4.500$, komisi untuk penjualan 20 exemplar dapat 1 exemplar harga jual.

2. Koran Tribun harga dari agen/ koordinator Rp 2.500 sedangkan harga jualnya Rp 3.000, komisi untuk penjualan 20 exemplar dapat 1 exemplar harga jual. 
3. Koran MX dan yang lainnya mendapat keuntungan Rp 500 per exemplar

Dari hasil penjualan tersebut ternyata mereka juga kadang-kadang mendapat uang lebih dari sipembeli Koran, menurut pengakuan mereka kalau Koran Riau Pos sebagian besar pembeli memberikan uang Rp 5.000 tanpa mau dikembalikan lagi. Untuk mengetahui berapa besar rata-rata pendapatan yang mereka peroleh setiap hari bahwa rata-rata tingkat pendapatan yang diperoleh para pedagang Koran asongan adalah dibawah Rp 50.000 yaitu sebanyak 25 orang responden $(62,5 \%)$ dan yang memperoleh pendapatan sebesar $\mathrm{Rp} 50.000$ sampai dengan Rp 100.000 adalah sebesar 14 orang (35\%) sedangkan diatas Rp 100.000 hanya 1 orang $(2,5 \%)$.

Selanjutnya uang yang mereka peroleh tersebut digunakan untuk kebutuhan hidup bersama keluarganya, untuk mengetahui keguanaan dari penghasilan penjualan Koran bahwa uang yang mereka peroleh dari hasil menjual Koran memang digunakan untuk membantu kebutuhan hidup keluarganya, hal ini ditunjukan dari hasil penelitian dilapangan bahwa 15 orang $(37,5 \%)$ mengatakan uang tersebut digunakan untuk biaya keperluan sekolah dan membantu orang tua, kemudian 10 orang (25\%) mengatakan bahwa uang tersebut digunakan untuk keperluan peribadi dan membantu kehidupan orang tua, dan hanya 4 orang $(10 \%)$ yang menyatakan uang tersebut digunakan untuk keperluan pribadi.

Fasilitas lain yang mereka peroleh dari hasil penjualan Koran tersebut adalah mendapatkan bonus jalan-jalan diwaktu hari libur sekolah antara lain adalah jalan-jalan ketempat rekreasi alam mayang, danau buatan atau pergi berenang, kemudian sewaktu memasuki hari raya mereka juga mendapatkan Tunjangan Hari Raya (THR) sebesar Rp 30.000 sampai dengan Rp50.000 perorang dan kain sarung serta pakaian dari para penerbit Koran tersebut.

\section{SIMPULAN}

Faktor yang menyebabkan anak-anak usia sekolah bekerja sebagai pedagang koran asongan adalah karena tidak memerlukan persyaratan yang berat, adanya kemauan dari dalam diri sendiri untuk bekerja dengan alasan untuk membiayai keperluan sekolah dan membantu kebutuhan hidup orang tua dan keluarganya dengan motivasi mendapatkan uang dalam melaksanakan pekerjaan. Adapun para pedagang koran asongan yang berada dalam usia sekolah, kebanyakan berusia berkisar antara 11 sampai dengan 15 tahun yakni sebanyak 21 orang $(52,5 \%)$, dengan tingkat pendidikan yang terbanyak adalah sekolah dasar yaitu sebanyak 19 orang (47,5\%), kemudian yang masih aktif sekolah adalah anak-anak SD sebanyak 16 orang atau sebesar $40 \%$.

Pola pekerjaan yang dilakukan oleh para pedagang koran asongan ini bervariasi, karena mereka selalu menyesuaikan waktunya dengan jam belajar disekolah. Jikalau mereka sekolah pagi maka ia akan berjualan pada siang hari dan kalau mereka sekolah siang hari maka ia akan berjualan pagi hari atau malam hari. Pekerjaan yang mereka lakukan di bawah pengawasan seorang koordinator atau agen secara langsung karena kalau koran tersebut tidak laku terjual maka akan dikembalikan kepada koordinator masing-masing.

Partisipasi mereka terhadap kesejahteraan keluarga sangat tinggi sekali walaupun pendapatan yang mereka terima mayoritas di bawah Rp 50.000 perharinya namun mereka tetap ingin membantu kehidupan keluarga. Hal ini dapat dibuktikan dengan penggunaan pendapatan yang mereka terima yaitu sebanyak 15 orang $(37,5 \%)$ menyatakan bahwa uang pendapatan tersebut digunakan untuk keperluan sekolah dan membantu orang tua, kemudian 10 orang (25\%) menyatakan bahwa pendapatan tersebut digunakan untuk keperluan pribadi dan membantu orang tua. 


\section{DAFTAR RUJUKAN}

Arifianto, Dessy, 2006, Tesis, Kajian Interaksi Aktifitas Pertokoan dan Pedagang Kaki Lima pada Trotoar dikawasan Perdagangan Banjaran Kabupaten Tegal, Program Pasca Sarjana Universitas Diponegoro,Semarang.

Agung Ridho, Muhammad, 2001, Kemiskinan di Perkotaan, Unissila Press, Semarang.

Boedion, 2002, Ekonomi Mikro. BPFE. Yogyakarta

Hafsah, Moh Jafar, 2003, Bisnis Ubi Kayu Indonesia, PT. Pustaka Sinar Harapan, Jakarta.

Hidayah, Nur, 2012, Strategi Bertahan Hidup Pedagang Asongan di Satasiun lampuyangan Yogyakarta dan Balapan Solo (Artikel), FISE, UNY, Yogyakarta.

Ibrahim, Jabal Tarik,2003,Sosiologi Pedesaan,UMM Press, Malang.

Nasution, Muslimin, 2002, Pengembangan Kelembagaan Koperasi Untuk Agroindustri, IPB Press, Jakarta.
Ningsih,Susanti, 2012, Potret Kehidupan Sosial Ekonomi Pedagang Asongan di FISIF Universitas Hasanudin Makasar, (Skripsi ).

Oktavyani, Artikel 26 juni 2010,( katuniakz@hotmail.com)

Reni, Sutyastie Soemitro, Tjiptoherianto. 2002. Kemiskinan dan Ketidakmerataan di Indonesia. Edisi Indonesia-Inggris. Rineka Cipta. Jakarta.

Resmi, Setia,2005, Gali Tutup Lubang itu Biasa, Strategi Buruh Menanggulangi Persoalan dari Waktu kewaktu, Yayasan Akatiga,Bandung.

Robinson Stephen and Timothy A.Judge,2007, Prilaku Organisasi, Salemba Empat, Jakarta

Sukirno, Sadono, 2002, Pengantar Teori Mikro Ekonomi, Edisi Ke III cetakan 18 , PT. Raja Grafindo Persada, Jakarta. 